\title{
AC 2010-1528: DEVELOPING A NEW CONSTRUCTION MANAGEMENT PROGRAM
}

\section{Tamara Chowdhury,}

Tamara Chowdhury is an Assistant Professor and Coordinator of Construction Management Program in the Department of Engineering Technology at Alabama A\&M University in Huntsville, AL. Mrs. Chowdhury has extensive background in teaching undergraduate students in the Department of Civil Engineering, Construction Management and conducting research. She also worked for a multinational research organization for many years. Mrs. Chowdhury earned her MS in Civil engineering from Clarkson University, New York, USA and B.S. in Civil Engineering from Bangladesh University of Engineering \& Technology. 


\title{
Developing a New Construction Management Program
}

\begin{abstract}
With the increasing complexity of constructing and maintaining infrastructure facilities, there has been a growing need for Construction Expertise to supplement the technical and managerial skills through construction and management related degrees in engineering \& technology. The means to acquire additional technical proficiency has been addressed quite adequately by a variety of Construction Management Degree Programs at many universities throughout the country, but the challenge to impart the requisite managerial skills has not been satisfied very effectively. Construction managers apply management and engineering techniques to the planning, design and construction of a project in order to control the time and cost to complete the project and the quality of the construction.

The Bachelor's Degree program in Construction Management offered by Alabama A\&M University, Normal, Alabama is designed to provide a foundation in construction management, construction engineering and legal issues relating to the construction management field. The program's multidisciplinary approach combines essential components of construction techniques with concepts of business management and behavioral science to develop technically qualified individuals for responsible management roles in the design, construction, and operation of major construction projects. In addition, Alabama A\&M University is considered as a Historically Black College \& University (HBCU), where over $90 \%$ students are underrepresented minority African-Americans. The mission of the program is to produce quality construction management graduates with technical and management skills that meet or exceed the expectations of industry, government, and graduate programs, and introduce diversity in the national workforce. The goals of the program are to prepare graduates for a lifelong professional career in the construction industry, meet the educational requirements for professional certification, and to provide graduates with solid academic preparation for graduate study. The construction industry needs qualified people who possess skills and knowledge in the management, engineering, economic and environmental aspects of construction projects.
\end{abstract}

\section{Introduction}

Alabama A\&M University (AAMU) offers a Bachelor of Science (B.S) degree in Construction Management (CMG) starting from Fall 2008. The CMG curriculum has been developed using the guidelines provided by the Associated Schools of Construction (ASC) and the Associated General Contractors (AGC) and designed to meet the requirements of accreditation board of American Council for Construction Education (ACCE) which is the predominant accreditation agency 
for construction management programs. Construction Management is the study of the management and engineering aspects of residential and commercial construction buildings, bridges, highways, power plants, water and waste water treatment facilities, and other public works essential to the quality of life of an industrial society. Construction managers apply management and engineering techniques to the planning, design and construction of a project in order to control the time and cost to complete the project and the quality of the construction. The construction industry needs qualified people who possess skills and knowledge in the management, engineering, economic and environmental aspects of construction projects.

The Bachelor's Degree program in Construction Management offered by AAMU is designed to provide a foundation in construction management, construction engineering and legal issues relating to the construction management field. The mission of the program is to produce quality construction management graduates with technical and management skills that meet or exceed the expectations of industry, government, and graduate programs. The goals of the program are to prepare graduates for a lifelong professional career in the construction industry, meet the educational requirements for professional certification, and to provide graduates with solid academic preparation for graduate study.

\section{Mission}

The mission of the Construction Management Program is to educate the students for professional construction leadership positions with a sense of ethical and environmental responsibility and also for advanced degree programs. The focus is on the fundamental concepts and technical skills required to create a wide range of career paths in the construction profession. We balance practical knowledge with theory. Through excellence in teaching, research and community service, the program promotes opportunities for scholarly, personal, and professional growth. We value and will continue our long tradition of educating non-traditional students of diverse backgrounds for successful entry into the workforce. The program is committed to School of Engineering and Technology maintaining scholarly activities to keep the program at the State of the Art of Application and seeks to provide service and outreach activities to the construction profession.

\section{Addressing the Need}

An increasingly strong demand is present for construction management graduates in the state of Alabama and nationwide. The construction industry has become a $\$ 500$ billion dollar per year industry marked by continuous and dramatic change. The demand for capable and highly trained construction management professionals, who can adapt and become effective leaders in the field, remains strong. There continues to be a growing demand for graduates of the construction 
management program. The increasing complexity of construction projects is boosting the demand for management-level personnel within the construction industry. Sophisticated technology and the proliferation of laws setting standards for buildings and construction materials, worker safety, energy efficiency, and environmental protection have further complicated the construction process. Advances in building materials and construction methods; the need to replace portions of the nation's infrastructure; and the growing number of multipurpose buildings and energy-efficient structures will further add to the demand for more construction managers. More opportunities for construction managers also will result from the need for greater cost control and financial management of projects and to oversee the numerous subcontractors being employed. The Bureau of Labor Statistics projects that excellent employment opportunities for construction managers are expected because the number of job openings will exceed the number of qualified individuals seeking to enter the occupation. This situation is expected to continue even as college construction management programs expand to meet the current high demand for graduates. In addition to job openings arising from employment growth, many additional openings should result annually from the need to replace workers who transfer to other occupations or who retire or leave the labor force for other reasons. More construction managers will be needed as the level of construction activity continues to grow. In addition, opportunities will increase for construction managers to start their own firms.

The program is a comprehensive major in construction management and is unique in the state of Alabama. The program is designed to also allow students with an approved A.A.S. or A.A.T. from a community college or technical college to obtain a 4 year degree in construction management. Numerous community colleges offering A.A.S. or A.A.T. programs in Building Construction Technology are very interested in this program.

The new Construction Management program at AAMU will meet the demand of students who are interested in construction management and it will increase the number of underrepresented minority African-Americans entering the construction industry.

\section{Development of Assessment and Improvement Plan}

The planning and evaluation process of the academic quality of the program contain measurable outcomes; a systematic means of collecting, quantifying, and analyzing data relevant to those outcomes; development of conclusions based on the data collected; and program modifications, when deemed appropriate to improve the program.

The Construction Management program at AAMU has been designed to meet accreditation board of the American Council for Construction Education (ACCE) which is the predominant accreditation agency for construction management 
programs. The curriculum, objective and learning outcome has been developed as per ABET model accreditation criteria ${ }^{1}$. The most recent criteria effective for evaluations can be found at ABET's website www.ABET.org.

The criteria allow some flexibility in program emphasis but are very explicit in that all technology programs must have:

- A set of "Program Educational Objections" which are statements of career and professional accomplishments that the program is preparing graduates to achieve.

- A set of "Program Outcomes" which are statements of what students are expected to know at graduation.

- An assessment process which measures the level of achievement of the educational and program objectives.

- A process through which results of assessment are applied to improve the program educational objectives and program outcomes.

Development of an assessment and improvement plan $^{1,2}$ for the new construction management program is in progress and has followed a four step process:

- Develop program educational objectives, program outcomes, and the supporting curriculum.

- Integrate program outcomes and curriculum.

- Develop an assessment plan.

- Develop an evaluation and improvement plan.

The continuous improvement plan and program assessment activities are shown in the flow chart below. 


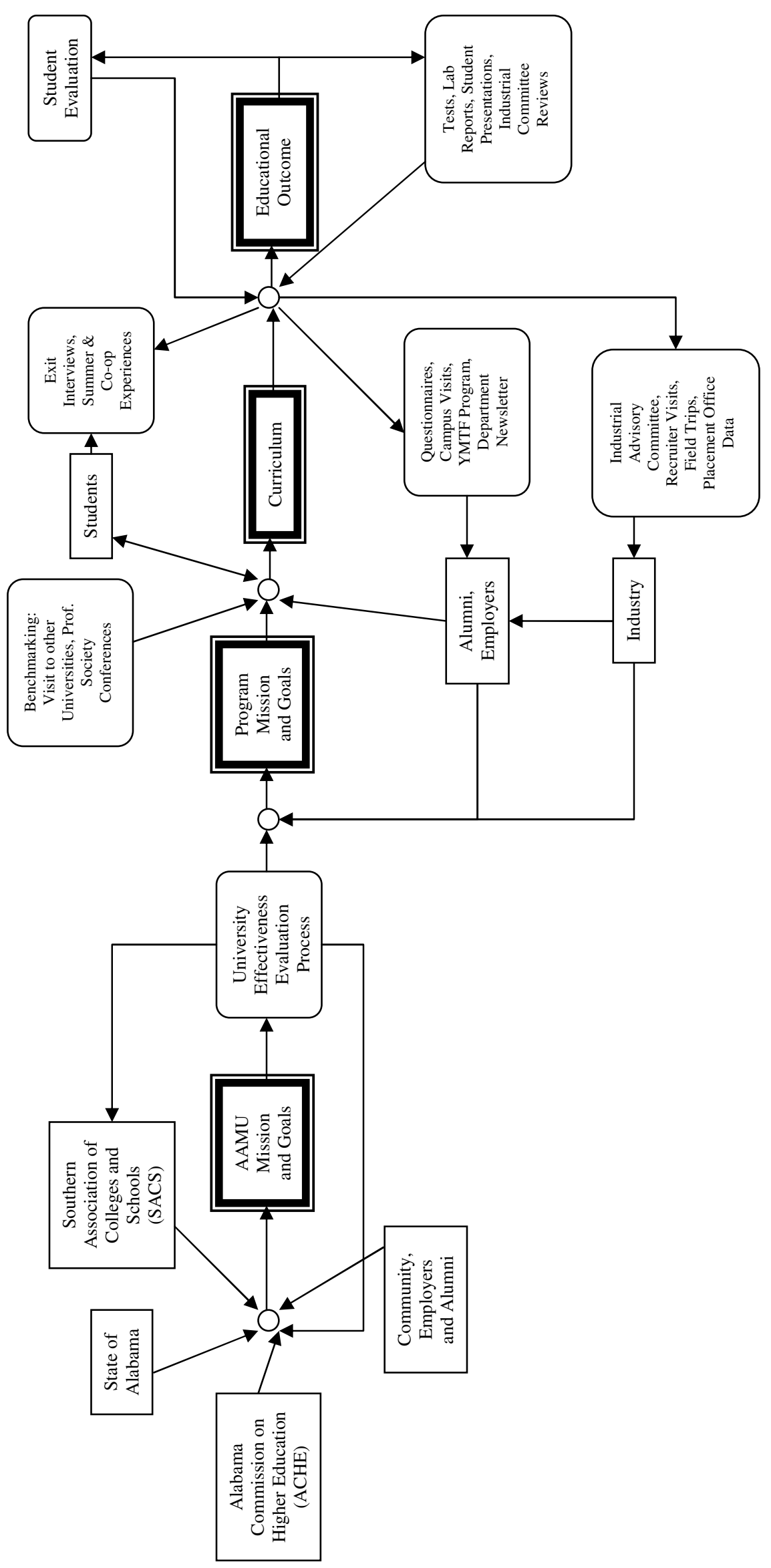

है

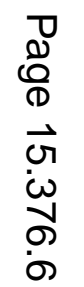




\section{Program Educational Objectives, Outcomes and Curriculum}

\section{Objectives}

- Organize and manage construction projects including scheduling, maintaining field records, team building and leadership concepts/skills.

- Ability to apply technical knowledge and prepare a complete construction project schedule to perform proficiently in construction industry.

- Conduct, analyze and interpret experiment related to construction and apply results to improve construction methods and technique.

- Communicate with multi-disciplinary teams

\section{Students Learning Outcome}

1. Ability to understand forces and force systems, able to determine resultant forces on structures and structural members and understand construction Methods \& Techniques.

2. Ability to use modern equipment and software necessary for construction practices.

3. Ability to plan, schedule, manage and complete a construction project.

4. Create a system or process in construction industry to meet desired needs within realistic constraints such as economic, environmental, social, ethical, health and safety, constructability and sustainability.

5. Ability to understand drawings, construction materials testing, building code requirements, construction law and contracts, quality control and quality assurance.

6. Communicate with multidisciplinary teams, leadership in construction and continue their education and professional development.

The Program Curricula, Mapping of CMG major courses to the Program Outcomes, Program Outcomes Assessment Plan, sample of Learning Outcome Rubric, sample of Student Learning Outcome Assessment Planning Matrix are shown in the following tables. 


\title{
PROGRAM CURRICULA CONSTRUCTION MANAGEMENT (BSCM)
}

\author{
127 Credit Hours
}

First Semester

ORI 101 Survival Skills

ENG 101 Composition I

CMG 101 Intro to Construction Mgmt

CMG 105 Intro to Construction Materials 2

MTH 112 Pre-Calculus Algebra 3

CHE 101 General Chemistry 3

CHE 101L General Chemistry Lab 1

Health, P.E., or Military Sci.

\section{Freshman Year}

Sem. Hrs. Second Semester

Sem. Hrs.

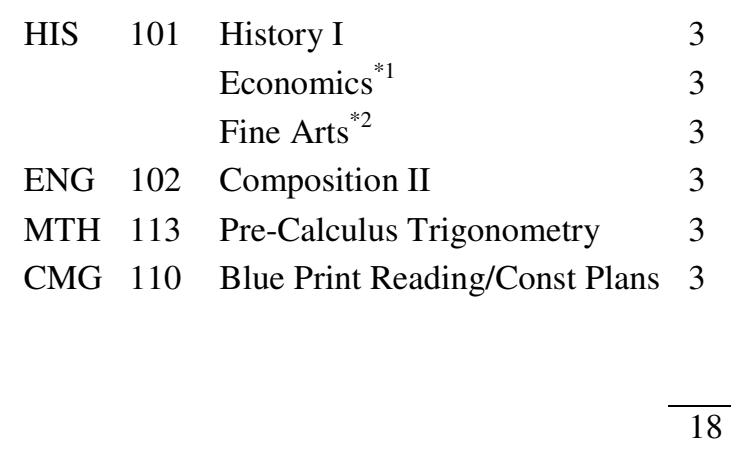

\section{Sophomore Year}

First Semester

Sem. Hrs.

Second Semester

Sem. Hrs.

$\begin{array}{lrlr} & & \text { Literature }^{*^{3}} & 3 \\ \text { HIS } & 102 & \text { History II } & 3 \\ & & \text { Natural/Physical Science Elective' } & 4 \\ \text { CE } & 201 & \text { Construction Surveying } & 3 \\ \text { TGC } & 217 & \text { Statics \& Structural Analysis } & 3\end{array}$

16

First Semester

Sem. Hrs.

Junior Year

\begin{tabular}{|c|c|c|c|}
\hline $\mathrm{CMG}$ & 300 & Construction Methods & 3 \\
\hline CMG & 301 & Construction Materials \&Testing & 3 \\
\hline CMG & 306 & Construction Planning \& Sched. & 3 \\
\hline CMG & 308 & Soil Mechanics \& Foundations & 3 \\
\hline \multirow[t]{2}{*}{ CMG } & 310 & Construction Contracts \& Law & 3 \\
\hline & & Business Elective $^{7}$ & 3 \\
\hline
\end{tabular}

Second Semester

Sem. Hrs.

CMG 315 Heavy Construction 3

CMG 318 Mechanical \& Electrical Systems 3

CMG 320 Leadership in Construction 3

CMG 325 Computer Applications for Const 3

CMG 350 Construction Safety 3

MGT 315 Principles of Management $\quad 3$

Senior Year

First Semester

Sem. Hrs.

Second Semester

Sem. Hrs.

\begin{tabular}{lllr} 
CMG & 400 & Construction Accounting & 3 \\
CMG & 410 & Concrete/Steel/Wood Des. \& Cor 3 \\
CMG & 420 & Internship & 3 \\
CMG & 430 & Advanced Const. Cost Estimation 3 \\
\hline
\end{tabular}

MGT 352 Entrepreneurship

3

CMG 450 Construction Codes \& Quality Contrc 3

CMG 460 Capstone Project

4

10

${ }^{1}$ Approved Economics - ECO 200, ECO 231, or ECO 232.

${ }^{2}$ Approved Fine Arts - ART 101 or MUS 101. ${ }^{3}$ Approved Literature - ENG 201 or ENG 203.

${ }^{4}$ Humanities - Approved course from literature, foreign languages, art, music, theater, and dance.

${ }^{5}$ Social Science - Approved course from economic, history, geography, psychology, political science, and sociology.

${ }^{6}$ BIO 101/101L Biology, PHY 101/102L Physics, CHE 102/102L Chemistry

${ }^{7}$ Business Elective - MGT 433, MGT 450, FIN 315 or other course approved by advisor. 


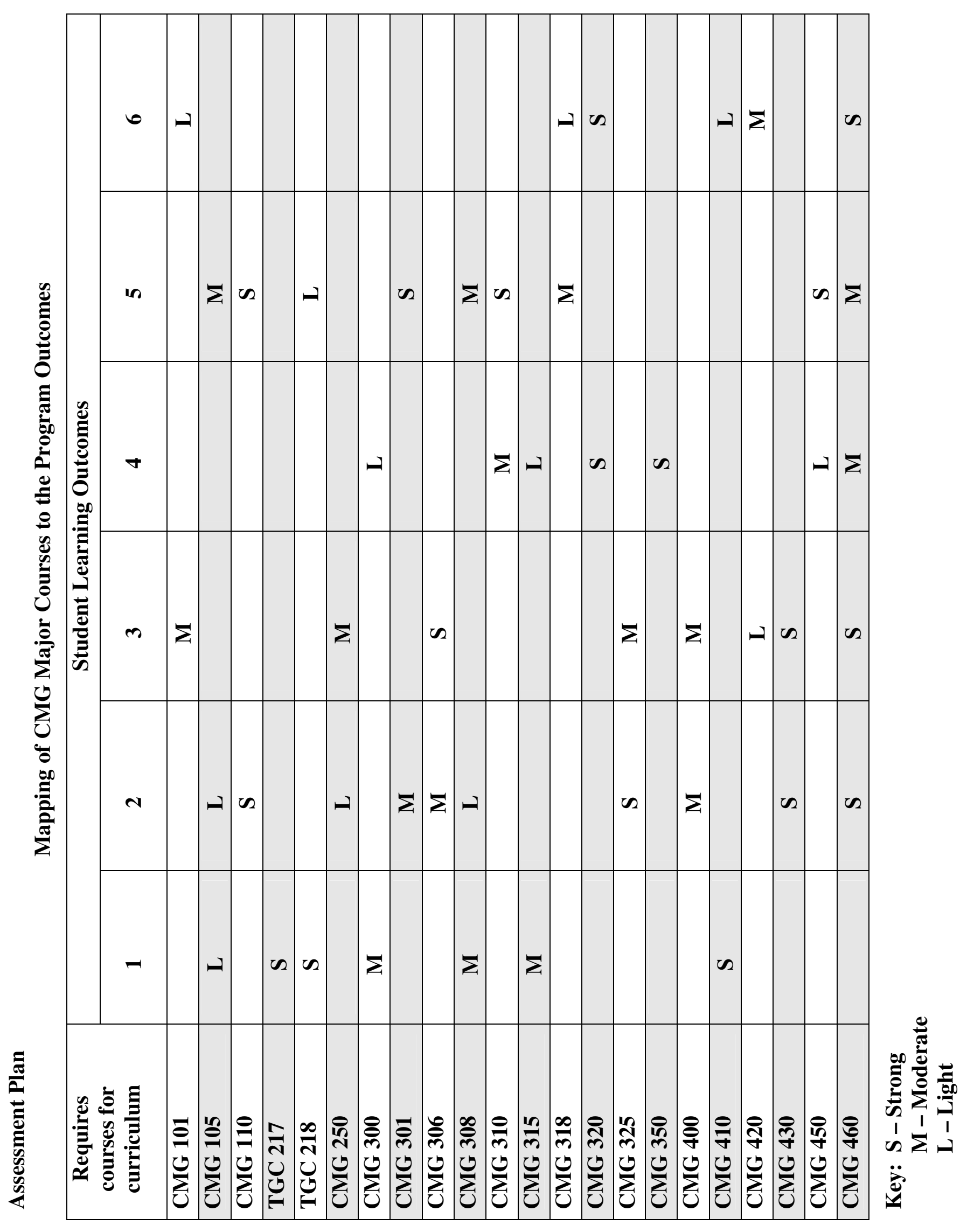




\begin{tabular}{|c|c|c|c|c|c|c|c|c|c|c|c|c|c|c|c|c|c|c|c|c|c|c|c|}
\hline & $\vec{J}$ & & & & & & & & & & & & & & & & & & & $\Sigma$ & & & $\boldsymbol{N}$ \\
\hline & $\ddot{\sigma}$ & & & & & & & & & & & & & & & & & & & $\Sigma$ & & & $\boldsymbol{\sim}$ \\
\hline & 6 & & & & & & & & & & & & & 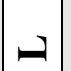 & & & & & & $\Sigma$ & & & 吸 \\
\hline & $\mathfrak{\sigma}$ & 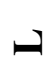 & & & & & & & & & & & & & $\boldsymbol{s}$ & & & & 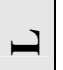 & $\Sigma$ & & & $\boldsymbol{N}$ \\
\hline & in & & & & & & & & $\boldsymbol{\Omega}$ & & & 曲 & & $\sum$ & & & & & & & & 吸 & $\sum$ \\
\hline & है & & $\Sigma$ & & & 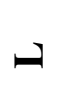 & & & $\boldsymbol{s}$ & & $\Sigma$ & & & & & & & & & & & & \\
\hline & ต็ & & & $\boldsymbol{\Omega}$ & & & & & & & & & & & & & & & & & & & $\Sigma$ \\
\hline & Z & & & & & & & $\boldsymbol{\prime}$ & & & & & $\boldsymbol{\prime}$ & & & & & & & & & 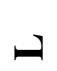 & $\sum$ \\
\hline$\tilde{E}$ & f & & & & & & & & & . & & $\Sigma$ & & & $\boldsymbol{\Omega}$ & & & & & & & & $\sum$ \\
\hline 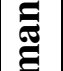 & $f$ & & & & & & & & & & & $\Sigma$ & & & & & & & & & & & $\Sigma$ \\
\hline$\stackrel{0}{\square}$ & $\mathscr{F}$ & & & & & & & & & & & & & & & & $\boldsymbol{\infty}$ & & & & & & $\sum$ \\
\hline & ले & & & & & & $\Sigma$ & & & $\boldsymbol{\Omega}$ & & & & & & $\Sigma$ & & & & | & $\boldsymbol{\Omega}$ & & Us \\
\hline & లో & $\Sigma$ & & & & & & & & $\boldsymbol{\Omega}$ & & & & & & - & & $\Sigma$ & & & & & 曲 \\
\hline & $\vec{\sim}$ & & & $\boldsymbol{\Omega}$ & & & এ & & & $\Sigma$ & & & & & & $\infty$ & & $\Sigma$ & & & $\boldsymbol{s}$ & & $\boldsymbol{U}$ \\
\hline & तึ & & এ & & & & & & $\Sigma$ & & এ & & & & & & & & & & & & \\
\hline & 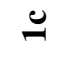 & & د & & $\boldsymbol{\Omega}$ & 曲 & & $\Sigma$ & & & $\Sigma$ & & $\Sigma$ & & & & & & $\boldsymbol{\infty}$ & & & & \\
\hline & 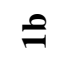 & & & & $\boldsymbol{\Omega}$ & Us & & $\Sigma$ & & & $\Sigma$ & & $\Sigma$ & & & & & & $\boldsymbol{\infty}$ & & & & \\
\hline & $\underline{\Xi}$ & & & & $\boldsymbol{\Omega}$ & 舟 & & & & & & & $\Sigma$ & & & & & & $\boldsymbol{\infty}$ & & & & \\
\hline
\end{tabular}

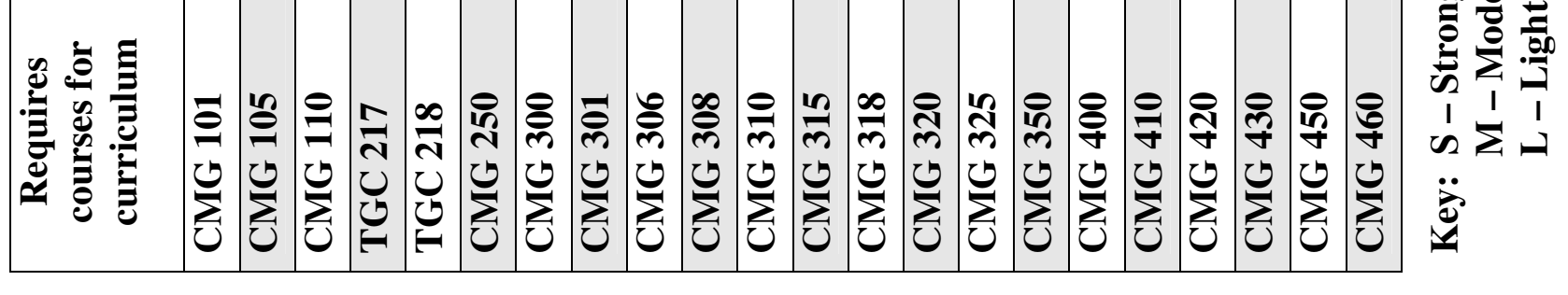

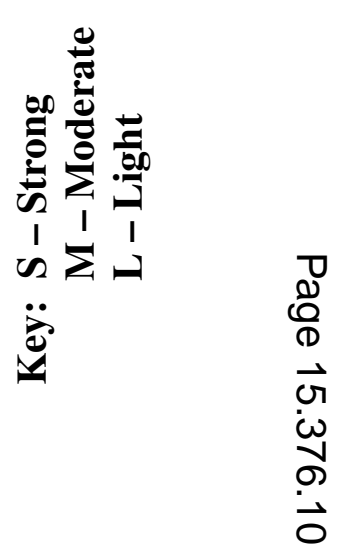




\section{Sample of Learning Outcome Rubric}

Learning Outcome: 1. Ability to understand forces and force systems. Able to determine resultant forces on structures and structural members and understand construction Methods \& Techniques.

Assessment Semester:

DFALL 20

DSPRING 20

\begin{tabular}{|c|c|c|c|c|c|c|}
\hline $\begin{array}{l}\text { Sr. } \\
\text { No. }\end{array}$ & $\begin{array}{l}\text { Performance } \\
\text { Criteria }\end{array}$ & $\begin{array}{c}\text { Unacceptable } \\
(0-0.74)\end{array}$ & $\begin{array}{c}\text { Marginal } \\
(0.75-1.74)\end{array}$ & $\begin{array}{c}\text { Acceptable } \\
(1.75-2.49)\end{array}$ & $\begin{array}{c}\text { Exceptional } \\
(2.5-3)\end{array}$ & Score \\
\hline $\mathbf{1 a}$ & $\begin{array}{l}\text { Identify and list } \\
\text { basic physical } \\
\text { principles and/or } \\
\text { theorems } \\
\text { necessary for } \\
\text { problem } \\
\text { formulation }\end{array}$ & $\begin{array}{l}\text { Most of the } \\
\text { relevant } \\
\text { principles and } \\
\text { theorems } \\
\text { identified are } \\
\text { missing }\end{array}$ & $\begin{array}{l}\text { Some relevant } \\
\text { principles and } \\
\text { theorems } \\
\text { identified but at } \\
\text { least } 1-2 \\
\text { important ones } \\
\text { missing }\end{array}$ & $\begin{array}{l}\text { Sufficient } \\
\text { relevant } \\
\text { principles and } \\
\text { theorems } \\
\text { identified but 1- } \\
2 \text { minor ones } \\
\text { missing }\end{array}$ & $\begin{array}{l}\square \text { All relevant } \\
\text { principles and } \\
\text { theorems } \\
\text { identified }\end{array}$ & \\
\hline $1 \mathrm{~b}$ & $\begin{array}{l}\text { Solve technical } \\
\text { problems } \\
\text { applying theorems } \\
\text { of Algebra, } \\
\text { Trigonometry, } \\
\text { Geometry, etc. }\end{array}$ & $\begin{array}{l}D \text { No significant } \\
\text { ability }\end{array}$ & $\square$ Some ability & $\begin{array}{l}\square \text { Sufficient } \\
\text { ability }\end{array}$ & $\square$ Agile ability & \\
\hline \multirow[t]{3}{*}{ 1c } & $\begin{array}{l}\text { Solve technical } \\
\text { problems using } \\
\text { the principles of } \\
\text { Science }\end{array}$ & $\begin{array}{l}\square \text { No significant } \\
\text { ability }\end{array}$ & $\square$ Some ability & $\begin{array}{l}\square \text { Sufficient } \\
\text { ability }\end{array}$ & $\square$ Agile ability & \\
\hline & $\begin{array}{c}\text { OVERALL } \\
\text { PERFORMANCE } \\
\end{array}$ & $\square$ Unacceptable & Marginal & $\square$ Acceptable & $\square$ Exceptional & AVERAGE \\
\hline & $\begin{array}{l}\text { AVERAGE } \\
\text { POINTS } \\
\text { REQUIRED }\end{array}$ & $(0-0.74)$ & $(0.75-1.74)$ & $(1.75-2.49)$ & $(2.5-3)$ & \\
\hline
\end{tabular}




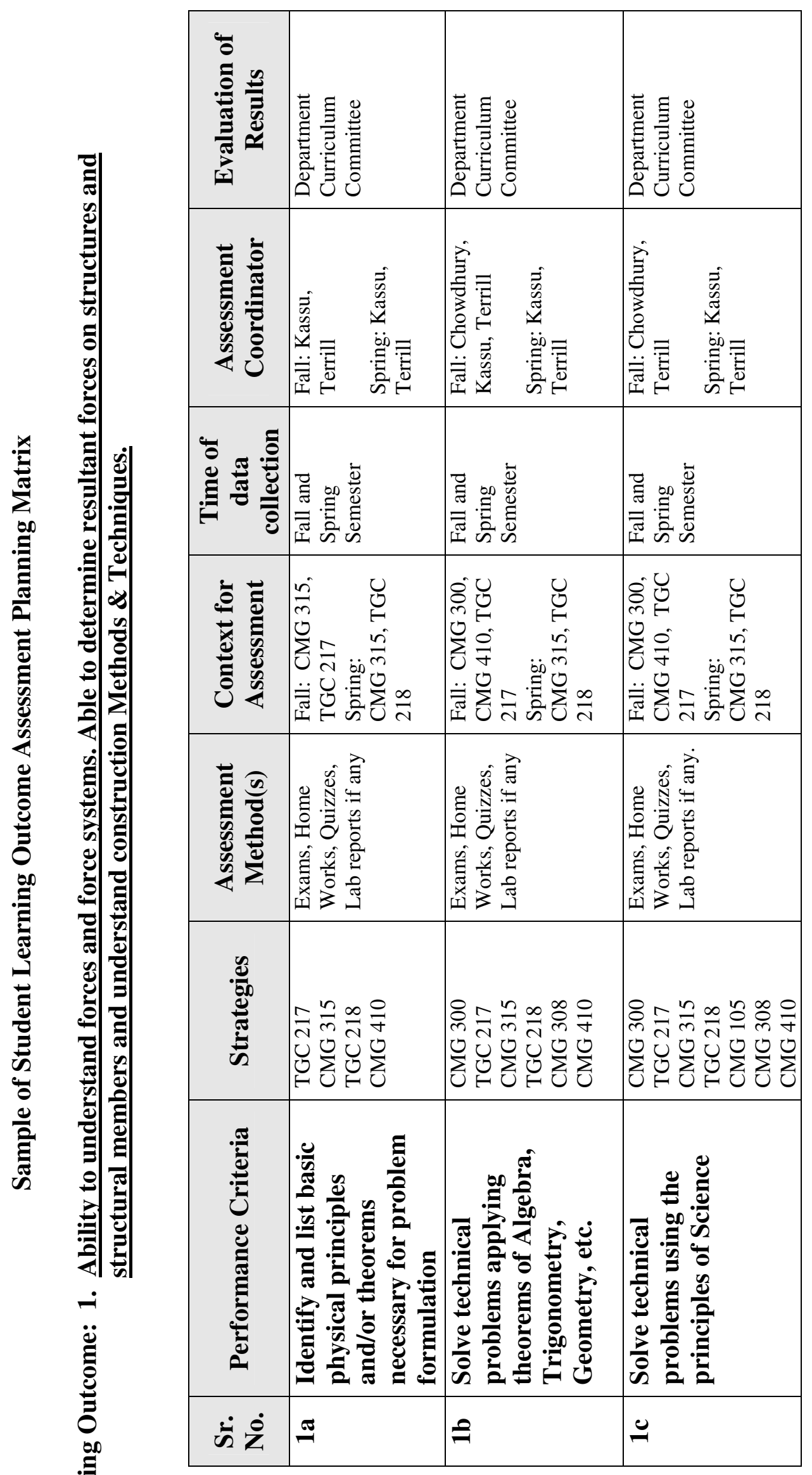

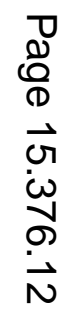




\section{Summary}

The construction management program is designed to meet all requirements for accreditation by the American Council for Construction Education (ACCE). Successful graduates will be qualified to take the State General Contractors examination to become a licensed Contractor. Through the Construction Management Association of America (CMAA) graduates can become Certified Professional Construction Managers. Through The American Society of Professional Estimators (ASPE) graduates can become Certified Construction Estimators. Other certifications and licensing opportunities will exist for graduates based on their use of elective courses and their personal career choices.

As has been discussed, building a new interdisciplinary program such as the construction management program is not an easy task. However, recognizing that such a program must function in a multidisciplinary environment and by providing the components necessary for it to succeed in such an environment can ensure success. Furthermore, by using the continuous improvement plan as a vehicle to design the program, collaboration among departments and within departments can be realized and a quality program maintained.

\section{Epilogue}

The culmination of our deliberations was realized in Summer 2007 when the Construction Management program was approved by ACHE, Alabama Commission on Higher Education. With little advertising in the website and other sources, currently 20 students enrolled in the program started in the fall semester of 2008. Enrollments increased in every semester and are expected to continue to rise.

\section{Reference}

1. "Criteria for Accrediting Engineering Programs" Effective for the 2007-2008 accreditation cycle, ABET, Engineering Accreditation Commission (EAC), ABET Inc., Baltimore, MD.

2. "Building a Construction Engineering Program" 2007 ASEE Annual Conference, AC 2007-822, Honolulu, Hawaii. 